\title{
Malignant transformation of osteoblastoma: Study using image analysis microdensitometry
}

J Grace, S McCarthy, R Stankovic, W Marsden

\begin{abstract}
Aim-To determine if the malignant transformation, as perceived histologically, in a case of osteoblastoma from the right femur, was also expressed as a quantitative change in nuclear DNA during tumour progression over five months.

Methods-Nuclear DNA microdensitometry by computer image analysis was used to acquire relative DNA distribution patterns. Tissue had been removed on four separate occasions from a lesion in the right femur of an 18 year old man. Retrospective DNA analysis was performed on formalin fixed, paraffin waxembedded tissue.

Results-The DNA profile of the initial biopsy specimen, which was histologically diagnosed as osteoblastoma, was euploid with a near diploid (2c) modal DNA. The second biopsy specimen taken one month later also resembled osteoblastoma but showed an aneuploid DNA profile with a diploid modal DNA and some nuclei with ploidy greater than 5c. The third biopsy specimen taken four months later showed histological evidence of osteosarcoma and a near pentaploid (5c) modal DNA with large number of nuclei exceeding $5 \mathrm{c}$.

Conclusions-DNA microdensitometry confirmed the initial and final diagnosis. The technique also seems to be capable of detecting aneuploidy before malignancy is morphologically evident.
\end{abstract}

$(\mathcal{O}$ Clin Pathol 1993;46:1024-1029)

Osteoblastoma is a rare osteoid producing bone neoplasm of osteoblastic origin. This is regarded by some as the benign counterpart of osteosarcoma, which in many cases is a highly malignant rapidly metastasising bone tumour. ${ }^{1}$

Most tumours diagnosed initially as osteoblastoma are cured by either intralesional or en bloc excision. About 10-15\%, however, behave aggressively with local recurrence. ${ }^{23}$ Some of these either undergo malignant transformation and metastasise or are reappraised as osteoblastoma-like osteosarcomas. ${ }^{1-9}$ Inadequate tumour sampling in such cases is possible, given that morphological heterogeneity exists within individual lesions of osteosarcoma. ${ }^{21011}$ DNA microdensitometry has been used as a diagnostic adjunct for neoplasms in which the diagnosis is equivocal. It may also have a more important and fundamental role in the investigation of the quantitative changes in nuclear DNA distribution associated with the process of malignant transformation.

\section{Case report}

An 18 year old man experienced worsening intermittent pain and swelling in his right thigh for a period of 14 months. The pain was temporarily relieved by mild analgesics and physiotherapy. Conventional radiography of his femur showed a prominent zone of pronounced cortical thickening and periosteal reaction involving the upper shaft. A zone of lucency measuring $35 \times 6 \mathrm{~mm}$ was present within the sclerotic area (fig 1).

On admission to hospital the patient's serum alkaline phosphatase was raised (202

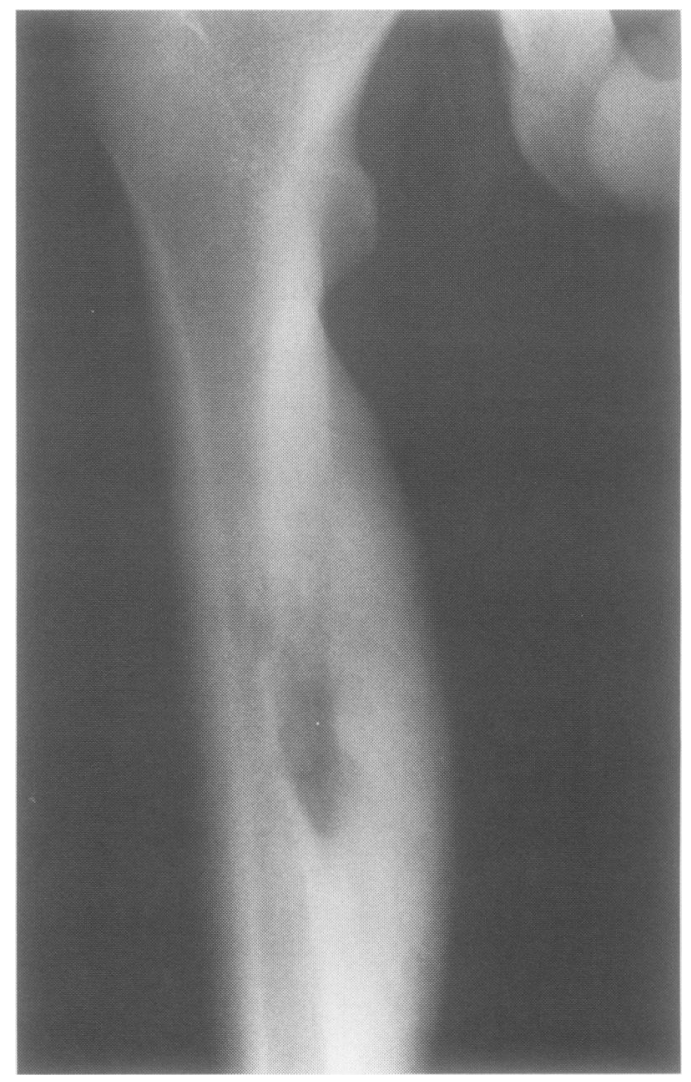

Figure 1 Initial radiograph of right femur showing obvious fusiform new bone formation mainly along the anteromedial aspect of the proximal third of the shaft. There is also a well defined central translucency $4 \mathrm{~cm}$ in length in the medial cortex abutting the endosteal surface. 
$\mathrm{U} / \mathrm{l}:$ range $<160 \mathrm{U} / \mathrm{l})$ while the serum calcium was normal $(2 \cdot 46 \mathrm{mmol} / \mathrm{l})$. Further $x$ ray pictures did not show any abnormalities in the patient's lungs, mediastinum, right tibia and fibula. An open biopsy specimen produced gritty, bloody tissue $10 \mathrm{~mm}$ and 8 $\mathrm{mm}$ across and several fragments of bone, including two cores. Histological examination showed vascular cellular osteoid tissue and with adjacent dense bone resembling osteoid osteoma (fig 2). Because the nidus radiologically exceeded $1.5 \mathrm{~cm}$, the lesion was classified as a benign osteoblastoma. ${ }^{12}$

After the biopsy there was a continuous ache in his right leg which was easily tolerated for one month. Then some dense cortical bone was removed and the nidus thoroughly curetted and filled with bone cement. Histological examination of the cortical bone specimens showed densely woven bone. The curetted tissue was similar to that seen in the first biopsy specimen showing highly vascular

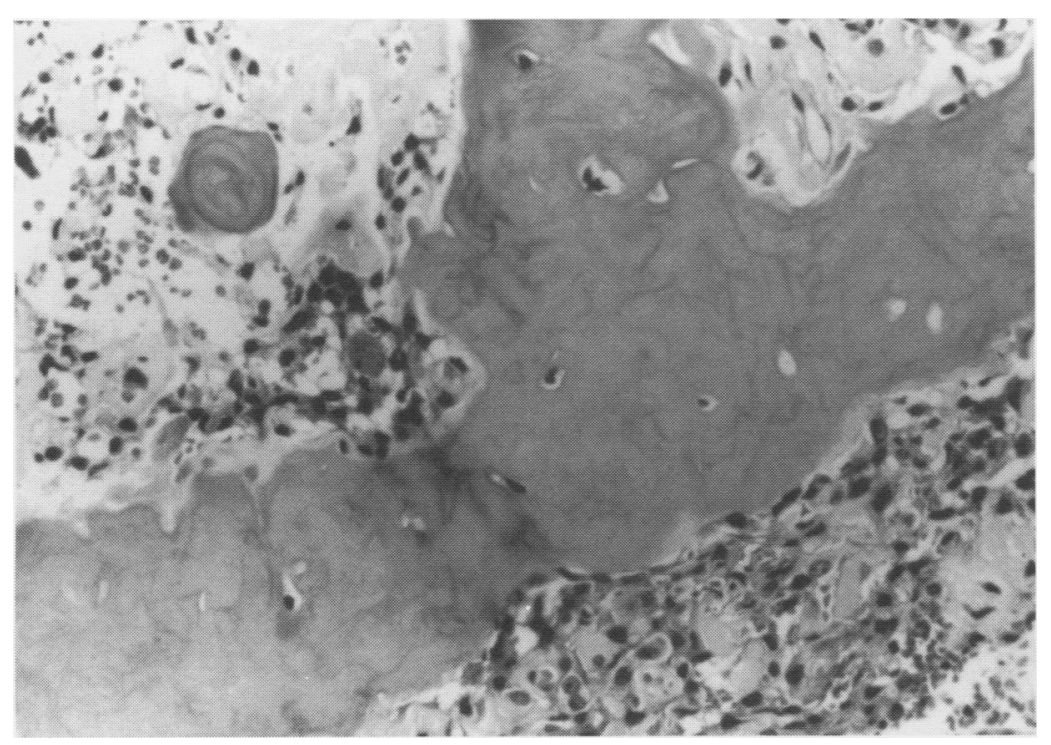

Figure 2 Initial biopsy specimen. Histological features of osteoblastoma showing minimal invasion of adjacent bone trabeculae.

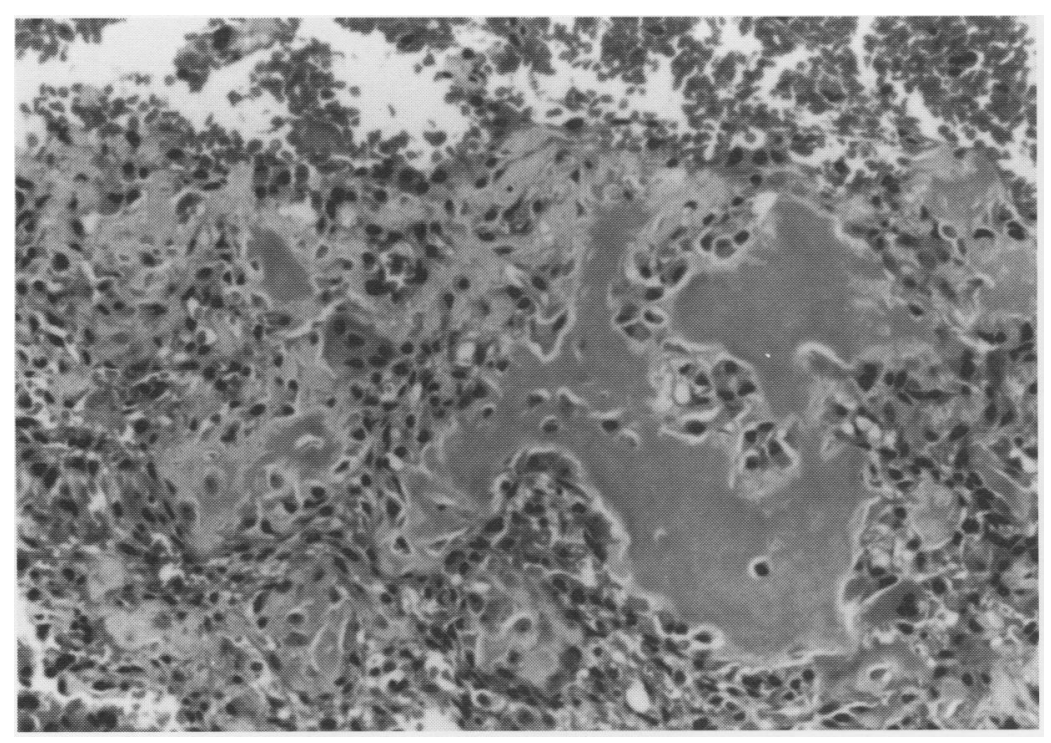

Figure 3 Residual osteoblastoma curetted before insertion of bone cement. osteoid containing numerous osteoblasts and scattered osteoclasts. On review some of this osteoblastic tissue seems to have permeated the dense bone (fig 3).

Four months later, after experiencing pain of greater intensity than ever before, the patient was re-admitted for surgery a third time. $X$ ray pictures showed an area of lucency around the upper half of the bone cement suggestive of a local recurrence (fig 4). The lesion was then curetted even more widely and treated with liquid nitrogen before packing it with bone chips from the iliac crest. Several pieces of cortical bone and curetted material were examined histologically. Some of the latter included fragments of abnormal osteoid with permeation of bone and moderate cellular pleomorphism, with up to $6 \mathrm{mitoses} / \mathrm{mm}^{2}$ and an occasional abnormal mitosis (figs 5A, B, 6A and B). Voluntary muscle and plasma cells were found within cortical bone in some sections. High grade osteoblastic osteosarcoma was diagnosed. This was later confirmed by Professor KK Unni from the Mayo Clinic, and after a three cycle regimen of intra-arterial chemotherapy en bloc diaphysial resection with intercalary reconstruction was performed.

New bone formation was found in the medullary cavity of a resected specimen which measured $180 \mathrm{~mm}$ in length. Histological examination showed no evidence of residual neoplasm. There was no clinical evidence of recurrence of metastatic disease 14 months after the resection.

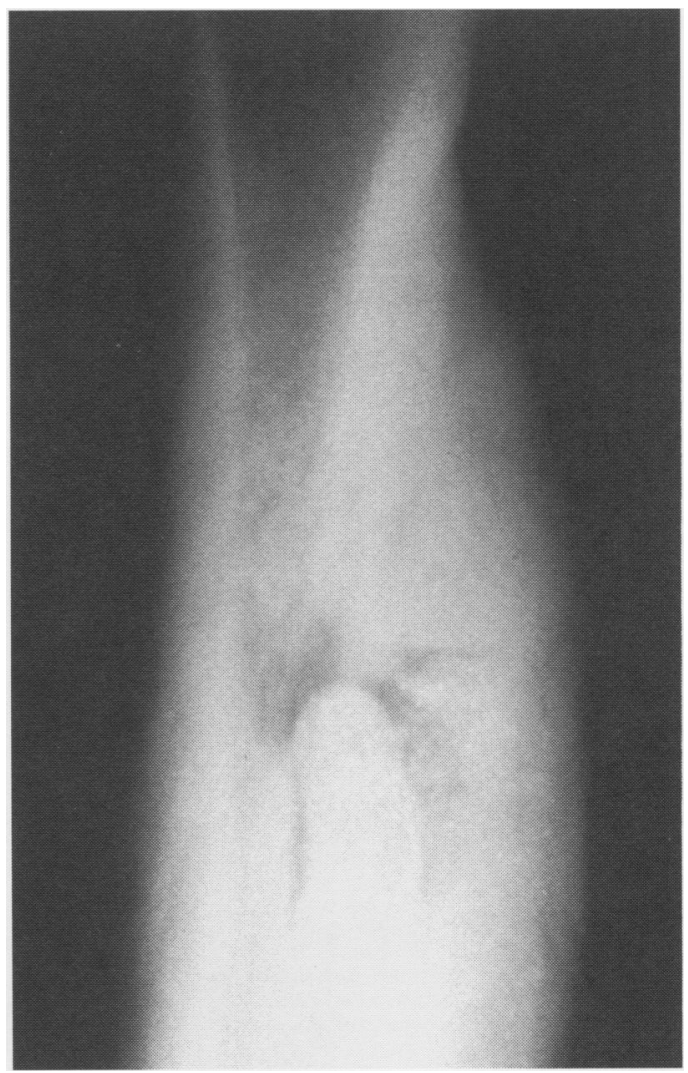

Figure 4 Radiograph four months after curettage and insertion of bone cement. The lucency around the proximal end of the cement had been increasing. Vascularity had also increased (angiogram). 


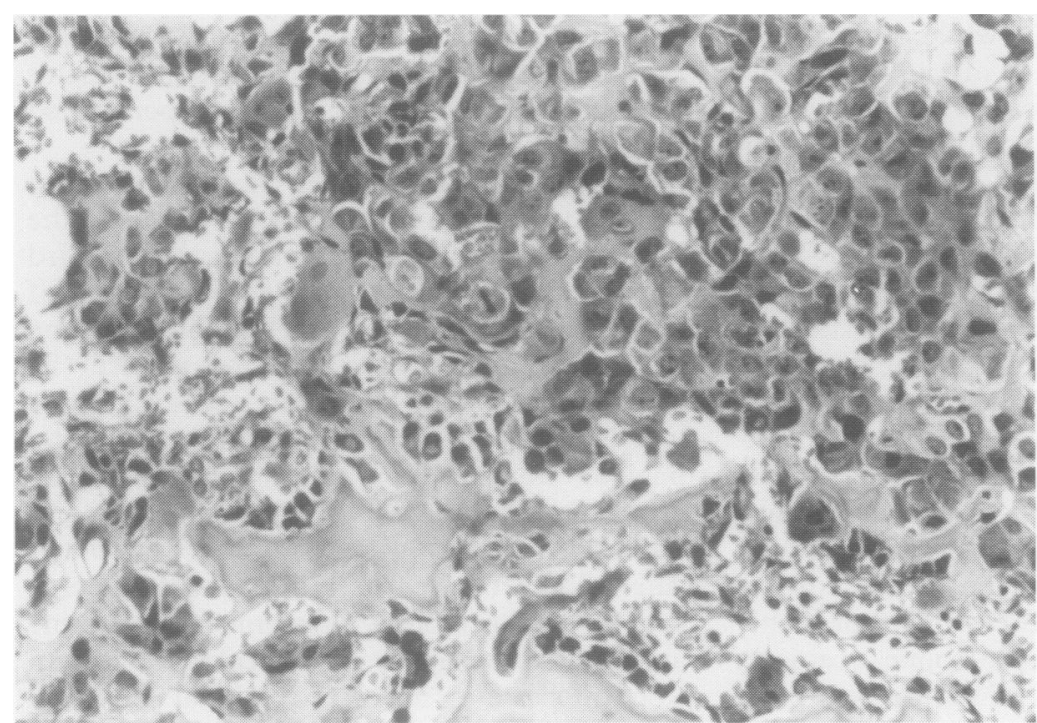

Figure 5A Before segmental resection the tumour shows pronounced cellular pleomorphism and invasion of adjacent bone.

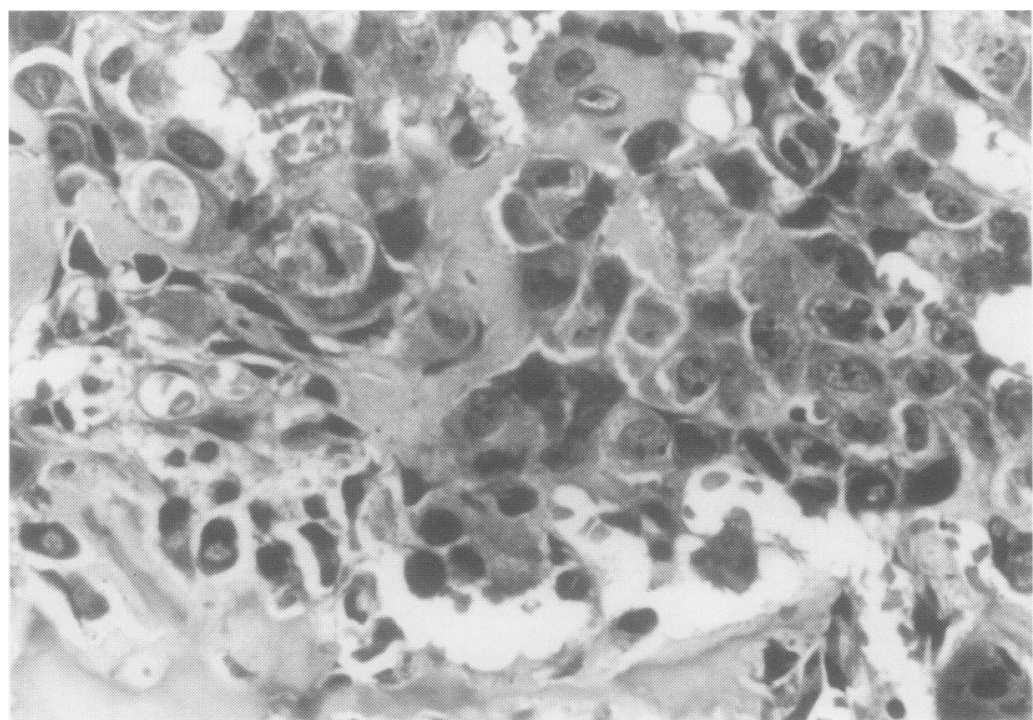

Figure 5B Higher power view to show cellular pleomorphism and abnormal mitosis.

Figure 6 Matching transmitted $(A)$ and polarised (B) light photomicrographs of identical fields, showing osteoblastoma-like osteosarcoma. Infiltration around partly eroded lamellar bone trabeculae is evident.

\section{Methods}

Fresh tissue was fixed for 24 hours in $10 \%$ neutral buffered formalin, then processed routinely, and embedded in paraffin wax. Blocks containing bone fragments were demineralised in RDO (Du Page Kinetic Laboratories, Illinois). Paraffin wax sections ( $6 \mu \mathrm{m}$ thick) were stained by a modified Feulgen method ${ }^{1314}$ using acid hydrolysis for 1 hour in $5 \mathrm{~N} \mathrm{HCl}$ at $22^{\circ} \mathrm{C}$ before staining with Schiff reagent for 15 minutes, prepared according to the method of de Tomasi. ${ }^{15}$ Sections were selected for DNA analysis based on areas that exhibited the most malignant pattern. ${ }^{16}$

The integrated optical density (IOD) of at least 100 diagnostic cells from each biopsy specimen was measured using the MD20 microcomputer system (Leica) for video image analysis and microdensitometry. ${ }^{17}$ This system consists of a high resolution solid state video camera mounted on a standard light microscope (Olympus BH2). The acquired images are digitised by an IBM/PC computer and IOD measurements are made on individually selected cells by grey level intensity thresholding and microdensitometry. Images can be edited to obtain precise threshold nuclear masking and corrections can be made which take into account irregularities in background illumination and inherent glare from the microscope optics.

Tumour associated lymphocytes were used as internal staining controls of the diploid DNA content. A diploid (2c) nuclear IOD value for each biopsy specimen was established from the lymphocyte measurements and used to convert the raw nuclear IOD values of the tumour cells to relative DNA values which are then displayed as ploidy frequency distributions. The raw measurement values and the diploid nuclear IOD values were also used to calculate various numeric indices of cell ploidy abnormality, including the $2 \mathrm{c}$ deviation index $(2 \mathrm{cDI})$ and the $5 c$ exceeding rate ( $5 \mathrm{cER}) .2 \mathrm{cDI}$ is defined as the mean square deviation from the diploid

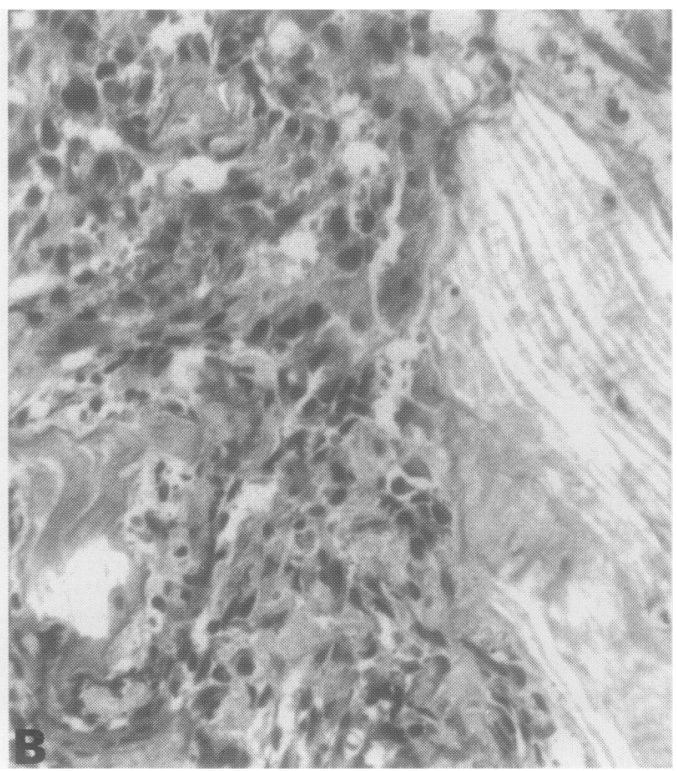




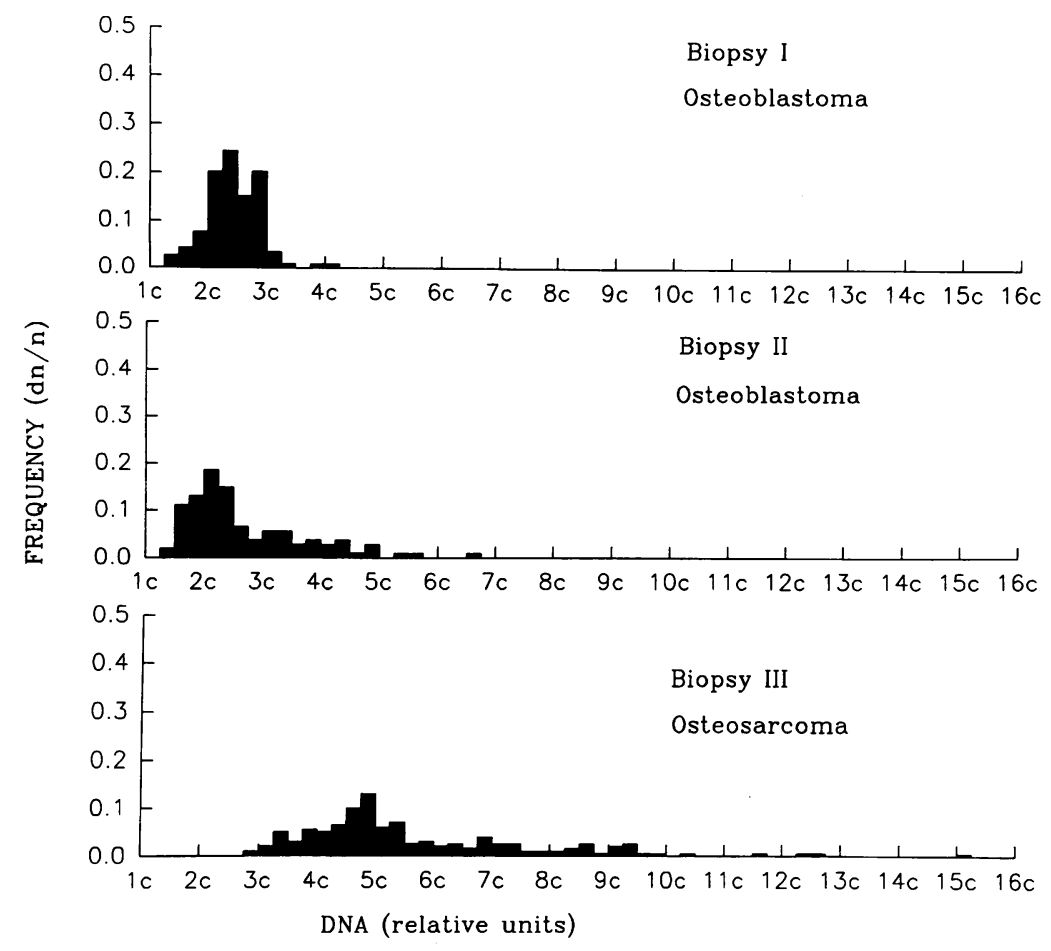

Figure 7 DNA frequency histograms. Biopsy specimen I: most cells are diploid. There are a small number of tetraploid cells, however, but no cells with ploidy greater than $5 c$. Biopsy specimen II: a more scattered DNA profile: most cells are diploid but some cells have ploidy greater than 5c. Biopsy specimen III: strongly aneuploid DNA distribution pattern with a near pentaploid (5c) modal DNA value and a significant number of cells that are positively aneuploid. ploidy was evident, as reflected by the gradual increased frequency of nuclei with DNA content greater than the tetraploid (4c) level. A gradual increase in the variance of the tumour cell population about the normal diploid (2c) value was also evident. Both biopsy specimens I and II showed near diploid (2c) modal DNA values, but nuclei with DNA content greater than $5 \mathrm{c}$ were detected in the latter. Morphologically and radiologically, the lesion in both these instances looked benign and was diagnosed as osteoblastoma. The Böcking algorithm, ${ }^{19}$ however, classifies biopsy specimen I as benign $\left(2 \mathrm{cDI}<\mathrm{bl}_{\mathrm{bo}}\right.$ and $5 \mathrm{cER}<0 \cdot 1)$ and biopsy specimen II as malignant ( $5 c E R>0 \cdot 1)$ (table). Four months later (biopsy specimen III) morphological evidence of a transformation was apparent. The DNA distribution pattern showed a near pentaploid (5c) modal DNA value and a significantly increased population of tumour cells with a DNA content greater than $5 c$.

An analysis of biopsy specimen IV was not performed. The exposure of tumour cells to cytostatic agents disqualified the specimen from submission to the algorithm. ${ }^{20}$

The malignancy grading of biopsy specimen II more than doubled in four months (biopsy specimen III). The results suggest that the tumour progressed from benign to high grade malignancy. The high number of mitotic figures noted in the second and third biopsy specimens compared with the low number in the initial biopsy specimen support the results.

A moderate reduction in Feulgen DNA stainability was noticed with the use of a commercially produced EDTA based decalcifying agent. Some authors advocate the use of EDTA-TRIS at pH $7 \cdot 0$ over other decalcifying agents on tissue requiring microspectrophotometric DNA analysis, reporting no modifications to the stoichiometric Feulgen reaction. ${ }^{21}$

Lymphocytes were chosen as internal staining controls in preference to fibroblasts or chondrocytes on the basis of greater uniformity in size and shape, and due to their small size the increased probability of measuring unsectioned lymphocytes. ${ }^{22}$ The modal control IOD value for the lymphocyte population, however, multiplied by a factor of $1 \cdot 15$ to take into account the condensed chromatin normally associated with Feulgen stained lymphocytes. ${ }^{23}$

\section{Discussion}

Recent advances in molecular genetics have elucidated some of the basic mechanisms involved in carcinogenesis by the discovery

Changes in tumour nuclear DNA indices over five months

\begin{tabular}{llllllll}
\hline & $\begin{array}{l}\text { Time after } \\
\text { initial biopsy } \\
\text { (months) }\end{array}$ & $2 c D I$ & $5 c E R$ & $D I$ & $M G$ & $\begin{array}{l}\text { Classification } \\
\text { by Böcking } \\
\text { algorithm }\end{array}$ & $\begin{array}{l}\text { Initial } \\
\text { diagnosis* }\end{array}$ \\
\hline I & 0 & 0.21 & 0.00 & 1.23 & N/A & Benign & Osteoblastoma \\
II & 1 & 1.77 & 4.63 & 1.35 & 0.78 & Malignant & $\begin{array}{l}\text { Osteoblastoma } \\
\text { III }\end{array}$ \\
\hline
\end{tabular}

^Based on clinical, radiological, and histopathological findings. N/A $=$ Not applicable to benign tumours. 
and characterisation of oncogenes and the role they have in malignant transformation. ${ }^{24} 25$ The activation and subsequent amplification of oncogenes or their inactivation and loss may result in structural or numeric chromosomal changes that can be detected by cytogenetic analysis. ${ }^{26}$ The procedure is technically difficult on solid tumours, however, and only produces a small percentage of interpretable results. Chromosomal changes accompanying the malignant transformation of a cell may be detected if large enough to procure a change in the total nuclear DNA content, resolvable as a ploidy aberration by quantitative nuclear cytophotometric or microdensitometric methods. ${ }^{1025}$ Microdensitometry in this study was used to investigate changes in nuclear DNA content of a bone tumour during its course through a morphologically perceived malignant transformation.

A review of published findings showed only three cases in which DNA analysis had been performed on osteoblastomas with malignant termination, none of which reported a progressive change in nuclear DNA content. Bauer et $a l^{1011}$ describe an osteoblastoma from the tibia of a 14 year old that recurred after open biopsy, reappearing six months later as an osteosarcoma. The patient showed no evidence of disease during 10 years of follow up after wide excision of the lesion. A similar case from the sacrum of a 31 year old was reported to have recurred nine months later as a high grade osteosarcoma. The patient died two years after intralesional excision of the tumour. The primary lesions from both patients were hyperploid by microspectrophotometric DNA analysis. Heliö et $a l^{27}$ described a bone tumour that was biopsied on three separate occasions over a period of 17 months, the first two biopsy specimens were diagnosed as osteoblastoma and osteosarcoma was diagnosed on the third and final biopsy specimen. Flow cytometric (FCM) analysis of the lesion showed an aneuploid peak in the DNA histograms of all three specimens.

A comparative analysis of results from independent studies should attempt to take the definitions used by each investigator into account. ${ }^{16}$ In several investigations using microspectrophotometric analysis, ${ }^{10112228-31}$ tumours were simply defined as diploid or hyperploid by placing an upper limit of diploidy based on DNA measurements made on internal control cell populations such as fibroblasts. Cells with DNA values exceeding those of proliferating diploid cells were not analysed and a definition or measure of aneuploidy was usually not attempted, which may explain why our results are at variance with those of other reports. ${ }^{101127}$

Our observations, however, cannot go unqualified without some reference to tumour representativity, considering that different biopsy procedures were used at various times, each of which yielded varying sample volumes from a morphologically heterogeneous bone tumour. Profuse bleeding from the lesion at investigative surgery largely accounted for the small volume of tissue procured during open biopsy in our study. The results and experience of other workers support our belief that the tumour was adequately biopsied on this occasion. Kreicbergs et $a l^{32}$ produced highly reproducible FCM DNA distribution curves of tumours sampled on different occasions-open biopsy and curative surgery. Bauer et al ${ }^{10}$ concluded that regardless of whether flow cytometry or cytophotometry is used, osteosarcomas express a uniform DNA content despite apparent morphological heterogeneity.

In most cases the ploidy profile of a bone tumour is strongly related to its histopathological diagnosis. ${ }^{11}$ Benign bone lesions are almost always diploid 1011162732 and classic osteosarcomas are predominantly hyperploid or aneuploid, with the exception of parosteal variants which are invariably diploid. ${ }^{10112829}$ 31-33 Among the classic osteosarcomas studied by Bauer et al, ${ }^{1029}$ modal DNA values in the triploid region predominated, while Kreicbergs et al $^{31} 32$ reported modal DNA values ranging from $2 \cdot 6 c-5 \cdot 4 c$ in one study and between $3 c-7 c$ in another. The near pentaploid modal DNA value obtained on the third biopsy specimen of the tumour in this study is within the range of values obtained by Kreicbergs et al.

The exceptional result obtained for the second biopsy specimen of our case study may prompt one to postulate the existence of a transitional stage where changes in nuclear DNA content precede a morphological change, to explain this observation. Experimental evidence exists, albeit indirect, to support this theory from a study on the pathogenesis of squamous cell carcinoma of the uterine cervix in mice treated with 3,4Benzopyrene. ${ }^{34}$ Morphological evidence of invasive carcinoma in this study was also preceded by the existence of atypical cells with increased nuclear DNA. A progressively increased and scattered DNA content was noted during the transformation to invasive carcinoma of the cervix.

Nuclear DNA microdensitometry was a helpful adjunct for the diagnosis of this bone tumour. It remains to be determined whether the technique has the potential to have an investigative role in the biology of malignant transformation and further our understanding of carcinogenesis.

1 Bertoni F, Unni KK, McLeod RA, Dahlin DC. Osteosarcoma resembling osteoblastoma. Cancer 1985; 55:416-26.

2 Jackson RP. Recurrent osteoblastoma: A review. Clin Orthop 1978;131:229-33.

3 Pieterse AS, Vernon-Roberts B, Paterson DC, Cornish BL, Lewis PR. Osteoid osteoma transforming to aggressive (low grade malignant) osteoblastoma: a case report and literature review. Histopathology 1983;7:789-800.

4 Revell PA, Scholtz CL. Aggressive osteoblastoma. 7 Pathol

5 Merryweather R, Middlemiss JH, Sanerkin NG. Malignant transformation of osteoblastoma. $\mathcal{F}$ Bone foint Surg 1980;62B:381-4.

6 Seki T, Fukuda H, Ishii Y, et al. Malignant transformation of benign osteoblastoma. $\mathcal{f}$ Bone foint Surg 1975;57: of benign 6 .

7 Jackson JR, Bell MEA. Spurious "benign osteoblastoma". 
A case report. F Bone foint Surg 1977;59-A:397-400. 8 Schajowicz F, Lemos C. Malignant osteoblastoma. $\mathcal{F}$ Bone foint Surg 1976;58-B:202-11.

9 Mirra JM, Kendrick RA, Kendrick RE. Pseudomalienant osteoblastoma versus arrested osteosarcoma. A case report. Cancer 1976;37:2005-14.

10 Bauer HCF DNA cytometry of osteosarcoma. Acta Orthop Scand 1988;59:Suppl 228.

11 Bauer HCF, Kreicbergs A, Silfverswärd C, Tribukait B DNA analysis in the differential diagnosis of osteosarcoma. Cancer 1988;61:1430-6.

12 Dalin DC, Unni KK. General aspects and data on 8,542 cases. In: Bone tumours. 4th Edn. Springfield, Illinois; Charles C Thomas, 1986;102-3.

13 De Cosse JJ, Aiello N. Feulgen hydrolysis: Effects of acid and temperature. $\mathcal{F}$ Histochem Cytochem 1966;14:601-4.

14 Eneroth CM, Zetterberg A. Microspectrophotometric DNA analysis of malignant salivary gland tumours. Acta Otolaryngol 1974;77:289-94.

15 De Tomasi F. Improving the technique of the Feulgen stain. Stain Technol 1936;11:137-41.

16 Mankin HJ, Gebhardt MC, Springfield DS, Litwak GJ Kusazaki K, Rosenberg AE. Flow cytometric studies of human osteosarcoma. Clin Orthop and Rel Res 1991;270 169-80.

17 Jarvis LR. A microcomputer system for video image analysis and diagnostic microdensitometry. Analyt Quan Cytol Histol 1986;8:201-9.

18 Böcking A, Adler C, Common HH, Hilgarth $M$, Granzen B, Auffermann W. Algorithm for a DNA-cytophotometric diagnosis and grading of malignancy. Analyt Quant Cytol 1984;6:1-7.

19 Böcking A Aufferman W. Algorithm for DNACytophotometric diagnosis and grading of malignancy. Cytophotometric diagnosis and grading

20 Böcking A, Aufferman W. Diagnose und gradierung bösartiger tumoren mit hilfeder DNS-bildztometrie. Leitz Mit Wiss Techn 1985;8:233-45.

21 Gimenez IB, Conti CJ, Cabrini RL. The effects of decalcification on the microspectrophotometric determination of DNA. Stain Technol 1977;52:352-3.

22 Kreicbergs A, Zetterberg A. Cytophotometric DNA measurements of chondrosarcoma. Methodologic aspects of measurements in tissue sections from old paraffin embedded specimens. Analyt Quant Cytol 1980 2:84-92.

23 Lockart RZ, Pezzella KM, Kelly MM, Toy ST. Features independent of stain intensity for evaluating Feulgen stained cells. Analyt Quant Cytol 1984;6:105-11.

24 Miller DM, Blume S, Borst M, et al. Oncogenes, malignant transformation and modern medicine. $A m \mathcal{F} \mathrm{Med}$ ;00:59-69.

25 Friedlander ML, Hedley DW, Taylor IW. Clinical and biological significance of aneuploidy in human tumours. f Clin Pathol 1984;37:961-74.

26 Atkin NB. Cytophotometric DNA determination correlated to karyotype, particularly in cancer. Analy Quant Cytol Histol 1987;9:96-104.

27 Heliö H, Karaharju E, Nordling S. Flow cytometric determination of DNA content in malignant and benign bone tumours. Cytometry 1985;6:165-71.

28 Kreicbergs A, Cewrien G, Tribukait B, Zetterberg A Comparative single-cell and flow DNA analysis of bone Comparative single-cell and flow DNA analy

29 Bauer HCF, Kreicbergs A, Silfverswärd C, Tribukait B. Ploidy and morphology in osteosarcoma. Analyt Quant Cytol Histol 1989;11:96-103.

30 Kreicbergs A, Zetterberg A, Söderberg G. The prognostic significance of nuclear DNA content in chondrosarcoma. Analyt Quant Cytol 1980;2:272-9.

31 Kreicbergs A, Broström L-Å, Cewrien G, Einhorn S Cellular DNA content in human osteosarcoma. Aspects on diagnosis and prognosis. Cancer 1982;50:2476-81.

32 Kreicbergs A, Silverswärd C, Tribukait B. Flow DNA analysis of primary bone tumours. Relationship between cellular DNA content and histopathologic classification Cancer 1984;53:129-36.

33 Xiang J, Spanier S, Benson NA, Braylan RC. Flow cytometric analysis of DNA in bone and soft-tissue tumours metric analysis of DNA in bone and soft-tissue tum

34 Näslund I, Rubio CA, Auer GU. Nuclear DNA changes during pathogenesis of squamous carcinoma of the cervix in 3,4-Benzopyrene-treated mice. Analyt Quan Cytol Histol 1987;9:411-8. 